\title{
The Beliefs of Obese People Towards Obesity
}

\author{
D Güzin Zeren Öztürk, ${ }^{1}$ (D) Saliha Buşra Aksu, ${ }^{1}$ (D) Memet Taşkın Egici \\ 'Department of Family Medicine, University of Health Sciences, Şişli Hamidiye Etfal Training and Research Hospital, \\ İstanbul, Turkey \\ ${ }^{2}$ Department of Family Medicine, University of Health Sciences, Haydarpaşa Numune Training and Research Hospital, \\ İstanbul, Turkey
}

\section{ABSTRACT}

Objectives: Obesity is a multifactorial complex disease that can be prevented. Obesity is a state of weight gain due to environmental factors and malnutrition and is effective in genetic factors, such as other chronic diseases. Obesity is defined as a body mass index (BMI) of $30 \mathrm{~kg} / \mathrm{m}^{2}$ or more. In this study, we aim to investigate the knowledge and behavior of obese people about obesity and give them feedback about their weight.

Methods: This study was conducted with participants who applied to the Family Medicine Clinic for any reason between 01.12.2018-31.12.2018. The questionnaire included questions about socio-demographic factors and their attitudes and knowledge about obesity. The data were collected by doctors using face-to-face interviews.

Results: One hundred thirty two obese were enrolled in the study. Seventy-one (53.8\%) of them were women. Seventy-two (54.5\%) of them were low educated and 84 (63.6\%) of them had low income. Female had higher BMI than men but there was no significant relationship (35.0 (30.0-51.0) kg/m² vs 34.0 (30.0-48.0) kg/ $\left.\mathrm{m}^{2}, \mathrm{p}=0.195\right)$. Obesity in family history was positive in $102(77.3 \%)$ of patients. BMI of participants with selfreported low daily exercise levels were significantly higher than those with self-reported high daily exercise levels $(p=0.014)$.

Please cite this article as: Öztürk GZ, Aksu SB, Egici MT. The Beliefs of Obese People Towards Obesity. Anatol J Family Med 2020;3(2):101-106.

Address for correspondence: Dr. Güzin Zeren Öztürk. Department of Family Medicine, Health Sciences University, Şişli Hamidiye Etfal Training and Research Hospital, İstanbul, Turkey

Phone: +90 5322930395

E-mail:

guzin_zeren@hotmail.com

Received Date: 15.06.2019

Accepted Date: 02.01.2020

Published online: 21.08.2020

(C) Copyright 2020 by Anatolian Journal of Family Medicine -

Available online at www.anatoljfm.org

OPEN ACCESS

Conclusion: Obesity is a long-term and complex problem and it is more than just what people eat. Additional studies are needed to investigate socio-economic, environmental and familial factors to understand its complexity.

Keywords: Obesity, body mass index, knowledge

\section{INTRODUCTION}

Obesity is the $5^{\text {th }}$ leading global risk for mortality in the world after high blood pressure (responsible for $13 \%$ of deaths globally), tobacco (9\%), high blood glucose $(6 \%)$ and physical inactivity (6\%). ${ }^{[1]}$ Obesity is a multifactorial complex disease that can be prevented. ${ }^{[2]}$ Obesity is a state of weight gain due to environmental factors and malnutrition and is effective in genetic factors, such as other chronic diseases. Major single genes that affect severe obesity and minor genes that affect fat distribution at early stages of obesity were shown; however, these genes can explain only a small portion of body weight variation in the population. ${ }^{[3]}$

In $2008,35 \%$ of the individuals were overweight at the age of 20 and over (34\% men and $35 \%$ women). The prevalence of obesity nearly doubled between 1980 and 2008. In 2008, $10 \%$ of the men and $14 \%$ of the women were obese, whereas, in 1980 , it was $5 \%$ for men, and $8 \%$ was for women. $38 \%$ of the world's adult population will be overweight, and $20 \%$ will be obese in 2030 according to this rate of increase. ${ }^{[4,5]}$ Overweight and obesity may lead to an increase in mortality and morbidity. Increasing Body Mass Index (BMI) is a risk factor for coro- 
nary heart disease, stroke and type 2 diabetes mellitus. ${ }^{[6]}$ $\mathrm{BMI}$ is calculated as the weight in kilograms divided by the square of the height in meters $\left(\mathrm{kg} / \mathrm{m}^{2}\right)$. Obesity is defined as BMI that is equal to $30 \mathrm{~kg} / \mathrm{m}^{2}$ or more. ${ }^{[4]}$ Prevention and management of obesity are responsibilities of all health care providers as it is a public health problem. ${ }^{[4]}$ National Health and Nutritional Examination Survey, which included 5000 participants, showed that the participants who were informed by their doctor about their weight were significantly more likely to lose weight by adopting a healthier lifestyle. ${ }^{[7]}$ This finding suggests that patients who are informed about obesity are becoming more aware and more willing to lose weight.

In this study, we aim to investigate the knowledge and beliefs of obese individuals about obesity and to raise their awareness.

\section{METHOD}

This study was conducted with the participants who applied to Şişli Hamidiye Etfal Research and Education Hospital Family Medicine Clinic for any reason between 01.12.2018-31.12.2018. Inclusion criteria were being over 18 years of age, having $\mathrm{BMI} \geq 30 \mathrm{~kg} / \mathrm{m}^{2}$ and not being a health care professional. Participants who were pregnant were not included in this study. The questionnaire included questions about socio-demographic factors and their beliefs about obesity. The questionnaire was performed by the doctors using face-to-face interviews.

Education levels were divided into two groups as follows: low educated group (less than high school) and highly educated group (high school and over). Income levels were divided into two as follows: low-income level ( $<2000$ Turkish Liras per month) and high income level ( $\geq 2000$ Turkish Liras per month). 2000 Turkish Liras per month is determined by reference to the minimum wage level in Turkey. ${ }^{[8]}$

After performing questionnaire, weight, height and waist circumference (WC) were measured using standard methods. WC was measured as the diameter at the level of the midpoint between the iliac crest and the lower border of the tenth rib. BMI was calculated as weight in kilogram divided by the square of height in meters $\left(\mathrm{kg} / \mathrm{m}^{2}\right) .{ }^{[9]}$

Data were analyzed using SPSS for Windows 20 package program. Descriptive statistics were presented as frequency, percentage, median, minimum and maximum. Categorical variables were analyzed using Pearson's ChiSquare test. The Kruskal-Wallis $\mathrm{H}$ and Mann Whitney $\mathrm{U}$ tests were used to compare variables among groups. We used an alpha (a) value of 0.05 as our significance level.

\section{RESULTS}

One hundred thirty-two obese were enrolled in the study. The distribution of socio-demographic characteristics and BMl of participants are shown in Table 1.

$\mathrm{BMI}$ of women with low education levels were significantly higher than women with high education levels $(p=0.025)$. The association between BMI, WC and socio-demographic

\section{Table 1. The distribution of the socio-demographic}

characteristics and body mass index

n (\%)

Gender

Female

$71(53.8)$

Male $61(46.2)$

Age groups (years)

Female

18-34

$17(23.9)$

35-49

$33(46.5)$

$50-64$

$15(21.1)$

$\geq 65$

$6(8.5)$

Male

18-34

$21(34.4)$

$35-49$

50-64

19 (31.1)

11 (18.1)

$\geq 65$

$10(16.4)$

Education

Female

Low education level

$49(69.0)$

High education level

22 (31.0)

Male

Low education level

$23(37.7)$

High education level

$38(62.3)$

Economic status

Female

Low-income level

51 (71.8)

High-income level

$20(28.2)$

Male

Low-income level

$33(54.1)$

High-income level

$28(45.9)$

BMI $\left(\mathrm{kg} / \mathrm{m}^{2}\right)$

Female

Obesity class I

$30(42.3)$

Obesity class II

28 (39.4)

Obesity class III

13 (18.3)

Male

Obesity class

Obesity class II

$11(18.0)$

Obesity class III

$9(14.8)$

BMI: Body Mass Index. 
characteristics are shown in Table 2.

When we asked the participants to report their daily exercise levels as three groups, 69 (52.3\%) of response was low level. BMI's of those with self-reported low daily exercise levels were significantly higher than BMI's those with selfreported high daily exercise levels $(p=0.014)$. The association between BMI, WC and daily exercise pattern are shown in Table 3.
One hundred two (77.3\%) of patients had family history of obesity. Family history of obesity was more frequent in patients whose BMI was higher $(p=0.006)$. The association between BMI, WC and obesity in family history are shown in Table 4.

Participants believed that the reason for obesity, 59 (44.7\%) of patients was abnormal nutrition and $30(22.7 \%)$ of patients low exercise. Besides, 80 (60.6\%) of patients thought that diet and 42 (31.8\%) of patients exercise were treatment

Table 2. The association between BMI, WC and socio-demographic characteristics

\begin{tabular}{|c|c|c|c|c|c|}
\hline & n (\%) & BMI $\left(\mathbf{k g} / \mathrm{m}^{2}\right)$ & $\mathbf{p}$ & $W C(\mathrm{~cm})$ & $\mathbf{p}$ \\
\hline Female & $71(53.8)$ & $35.0(30.0-51.0)$ & $0.195^{*}$ & $104.0(84.0-130.0)$ & 0.378 \\
\hline \multicolumn{6}{|l|}{ Age groups (years) } \\
\hline $18-34$ & $38(28.8)$ & $33.5(30.0-42.0)$ & \multirow{3}{*}{$0.340^{+}$} & $100.0(80.0-132.0)$ & \multirow{3}{*}{$0.023^{+}$} \\
\hline $50-64$ & $26(19.7)$ & $35.0(30.0-48.0)$ & & $108.0(89.0-128.0)$ & \\
\hline$\geq 65$ & $16(12.1)$ & $34.0(31.0-44.0)$ & & $101.5(84.0-118.0)$ & \\
\hline \multicolumn{6}{|l|}{ Education } \\
\hline \multicolumn{6}{|l|}{ Female } \\
\hline Less than high school & $49(69.0)$ & $36.0(30.0-51.0)$ & $0.025^{*}$ & $104.0(84.0-128.0)$ & 0.103 \\
\hline High school and over & $38(62.3)$ & $34.0(30.0-47.0)$ & $0.367^{*}$ & $105.0(80.0-132.0)$ & 0.432 \\
\hline \multicolumn{6}{|l|}{ Economic status } \\
\hline \multicolumn{6}{|l|}{ Female } \\
\hline$<2000 \mathrm{TL}$ & $51(71.8)$ & $35.0(30.0-51.0)$ & \multirow{2}{*}{$0.096^{*}$} & $104.0(95.0-132.0)$ & \multirow{2}{*}{0.367} \\
\hline$\geq 2000 \mathrm{TL}$ & $20(28.2)$ & $35.0(30.0-48.0)$ & & $101.0(80.0-130.0)$ & \\
\hline \multicolumn{6}{|l|}{ Male } \\
\hline$<2000 \mathrm{TL}$ & $33(54.1)$ & $34.0(30.0-51.0)$ & \multirow{2}{*}{$0.237^{*}$} & $104.0(95.0-132.0)$ & \multirow{2}{*}{0.173} \\
\hline$\geq 2000 \mathrm{TL}$ & $28(45.9)$ & $33.0(30.0-48.0)$ & & $101.0(80.0-130.0)$ & \\
\hline \multicolumn{6}{|c|}{ BMI: Body Mass Index; WC: waist circumference. } \\
\hline
\end{tabular}

\section{Table 3. The association between BMI, WC and daily exercise pattern}

\begin{tabular}{lcccr} 
Daily exercise pattern & $\mathbf{n}(\%)$ & BMI $\left(\mathbf{k g} / \mathbf{m}^{2}\right)$ & $\mathbf{p}$ & WC (cm) \\
\hline Low & $69(52.3)$ & $35.0(30.0-51.0)$ & & $104.0(80.0-130.0)$ \\
Medium & $47(35.6)$ & $33.0(30.0-46.0)$ & 0.014 & $103.0(84.0-132.0)$ \\
High & $16(12.1)$ & $32.0(30.0-40.0)$ & & $100.0(85.0-118.0)$
\end{tabular}

BMI: Body Mass Index; WC: waist circumference.

Data is presented as median (minimum-maximum).

Kruskal-Wallis Test. 
Table 4. The association between BMI, WC and family history of obesity

\begin{tabular}{|c|c|c|c|c|c|}
\hline Family history of obesity & n (\%) & BMI $\left(\mathbf{k g} / \mathrm{m}^{2}\right)$ & $\mathbf{p}$ & WC (cm) & $\mathbf{p}$ \\
\hline No & $30(22.7)$ & $32.0(30.0-44.0)$ & 0.014 & $102.5(80.0-121.0)$ & 0.144 \\
\hline \multicolumn{6}{|c|}{ BMI: Body Mass Index; WC: waist circumference. } \\
\hline \multicolumn{6}{|c|}{ Data is presented as median (minimum-maximum). } \\
\hline Mann-Whitney U Test. & & & & & \\
\hline
\end{tabular}

of obesity. Twenty-seven (20.5\%) of responders applied to a doctor, and it was determined that the reason of 45 (34.1\%) patients who did not apply a doctor was neglect.

\section{DISCUSSION}

This study aims to compare the socio-demographic characteristics of the people with obesity and their beliefs about it. More than half of the participants were women in our study, and it was expected, as female obesity is more frequent in Turkey as it is in the world..$^{[10,11]}$

In our study, we found that the result of education on general obesity was similar in both genders, educated people have lower BMI and in low educated women, general obesity was statistically significant. Hajian-Tilaki et al. found consistent results with our work. ${ }^{[12]}$ As the level of education increases, the standard of knowledge about the results of obesity may increase, and behavioral measures may be taken. People who are more educated have healthier lifestyles. Educated people may be more aware of obesity and its complications, and they tend to have a healthier diet that contains more fruits, vegetables and lower-fat milk and less fat. ${ }^{[13,14]}$

The level of education gained in early adulthood remains almost the same throughout life, which makes it an easy and reliable indicator; however, the social status may change with income levels. Income primarily affects the ability to spend money to buy healthier food and to have physical activities. ${ }^{[15]}$

In our study, we found that individuals exposed to lowincome are more likely to have higher BMl; our results were similar to a meta-analysis carried out by Kim et al. ${ }^{[16]}$ Having a healthier diet costs more money ${ }^{[17,18]}$ A study revealed that obesity-promoting foods have a lower cost. [19] The United Kingdom Women's Cohort Study showed that women with a healthier diet spent an additional 617 pounds sterling $\left(\approx\right.$ US\$1000) per year. ${ }^{[20]}$

In our study, we found that people with a positive family history of obesity have significantly higher BMI. In a study among children under 10 years of age, parental obesity was defined as a risk of adult obesity. ${ }^{[21]}$ Familial history is a pre- disposition factor in many disorders. ${ }^{[22]}$ Monozygotic twins have more similar diseases and acquisition of fat compared to dizygotic twins. ${ }^{[23,24]}$ Family history and genes remain to be unalterable, but healthy eating habits and physical activity will change and improve the next generation. ${ }^{[25]}$

Most of our participants directed the reason for obesity as abnormal nutrition and low exercise and the cure as exercise and dieting. Also, individuals with self-reported low exercise levels have significantly higher BMI levels and higher WC. In the decades, many studies focused on the relation between obesity and behavioral change treatments. Having a healthy diet and physical activity decrease obesity. [26] Studies showed that caloric restriction, a healthier diet combined with 150-250 minutes per week of moderateintensity activity is associated with better weight outcomes. ${ }^{[27,28]}$ Physical activity is proved to decrease the risk for chronic diseases, including obesity, in active compared with inactive adults. ${ }^{[29]}$

Question that needs to be asked; what are factors that make individuals increase their physical activity level and adopt a healthy diet so that long-term behavior change can be achieved. ${ }^{[30]}$ We may push people to understand that obesity is a health problem. Prevention is the key in case of obesity rather than treatment.

This study has several limitations. Obesity arises as a result of the complex relationship between the individual's genetic and environmental factors. It is often exacerbated or weakened by the influences of non-genetic factors, regardless of the impacts of genetic factors. Choosing only education and income among social determinants of health is an important limitation of this study. A further limitation in this study was the use of the self-reported family history of obesity.

\section{CONCLUSION}

The results of this study indicate that education has an inverse relation with general obesity in women, whereas men with higher education had lower BMI. Women and men with monthly low-income levels had higher BMI. Additional studies are needed to investigate lifestyle factors 
that are modified by education and socio-economic status in both genders. The positive family history about obesity were more frequent in people whose BMI was higher. The most common reason for not applying to doctor was disregard of the patients about obesity. Education programs should be designed about obesity and their complications to prevent the population.

\section{Disclosures}

Peer-review: Externally peer-reviewed.

Conflict of Interest: None declared.

Ethics Committee Approval: This study was approved by the ethics and research committee of Şişli Hamidiye Etfal Education and Research Hospital (Approval number: 2182, Approval date: 20 Nov 2018) and verbal consent was obtained from each participant.

Authorship Contributions: Concept - G.Z.Ö.; Design - G.Z.Ö., S.B.A.; Supervision - G.Z.Ö.; Materials - G.Z.Ö., S.B.A.; Data collection \&/or processing - G.Z.Ö., S.B.A.; Analysis and/or interpretation - G.Z.Ö., M.T.E.; Literature search - G.Z.Ö., M.T.E.; Writing S.B.A.; Critical review - G.Z.Ö., M.T.E.

\section{REFERENCES}

1. World Health Organization. Global Health Risks: Mortality and burden of disease attributable to selected major risks, Geneva, 2009. Available at: http://www.who.int/healthinfo/global_ burden_disease/GlobalHealthRisks_report_full.pdf Accessed Mar 11, 2020.

2. Ng M, Fleming T, Robinson $M$, Thomson B, Graetz N, Margono $C$, et al. Global, regional, and national prevalence of overweight and obesity in children and adults during 1980-2013: a systematic analysis for the Global Burden of Disease Study 2013. Lancet 2014;384(9945):766-81.

3. Farooqi S, O'Rahilly S. Genetics of obesity in humans. Endocr Rev 2006;27(7):710-8.

4. World Health Organization. Obesity: preventing and managing the global epidemic: report of a WHO Consultation on Obesity, Geneva, 3-5 June 1997. Available at: https://apps. who.int/iris/handle/10665/63854. Accessed Mar 11, 2020.

5. Kelly T, Yang W, Chen CS, Reynolds K, He J. Global burden of obesity in 2005 and projections to 2030. Int J Obes (Lond) 2008;32(9):1431-7.

6. Global risks 2010: A Global Risk Network Report Geneva, World Economic Forum, 2010. Available at: http://afyonluoglu.org/ PublicWebFiles/Reports-CS/WEF-GRR/2010\%20WEF\%20 Global\%20Risks\%20Report\%2005-2010.pdf. Accessed Mar 11, 2020.

7. Pool AC, Kraschnewski JL, Cover LA, Lehman EB, Stuckey HL, Hwang KO, et al. The impact of physician weight discussion on weight loss in US adults. Obes Res Clin Pract 2014;8(2):e131-9.
8. Asgari Ücret-2020. TC Aile, Çalışma ve Sosyal Hizmetler Bakanlığı. Available at: https://www.ailevecalisma.gov.tr/tr-tr/ asgari-ucret/ Accessed, Aug 2020.

9. World Health OrganisationBody Mass Index-BMI. Available at: http://www.euro.who.int/en/health-topics/disease-prevention/nutrition/a-healthy-lifestyle/body-mass-index-bmi. Accessed Mar 11, 2020.

10. T.C. Halk Sağlığı Genel Müdürlüğü. Türkiye'de Obezitenin Görülme Sıklığı. Available at:https://hsgm.saglik.gov.tr/tr/ obezite/turkiyede-obezitenin-gorulme-sikligi.html. Accessed Mar 11, 2020.

11. Ritchie $\mathrm{H}$, Roser M. Obesity\&BMI. Our World in Data. Available at: https://ourworldindata.org/obesity\#prevalence-of-obesity-by-gender. Accessed Mar 11, 2020.

12. Hajian-Tilaki KO, Heidari B. Association of educational level with risk of obesity and abdominal obesity in Iranian adults. J Public Health (Oxf) 2010;32(2):202-9.

13. McLaren L. Socioeconomic status and obesity. Epidemiol Rev 2007;29:29-48.

14. Power EM. Determinants of healthy eating among low-income Canadians. Can J Public Health 2005;96(4):S37-S48.

15. Kushi LH, Folsom AR, Jacobs DR Jr, Luepker RV, Elmer PJ, Blackburn $\mathrm{H}$. Educational attainment and nutrient consumption patterns: the Minnesota Heart Survey. J Am Diet Assoc 1988;88(10):1230-6.

16. Kim TJ, von dem Knesebeck O. Income and obesity: what is the direction of the relationship? A systematic review and meta-analysis. BMJ Open 2018;8(1):e019862.

17. Michaud C, Baudier F, Loundou A, Le Bihan G, Janvrin MP, Rotily $M$. Food habits, consumption, and knowledge of a lowincome French population.[Article in French] Sante Publique 1998;10(3):333-47.

18. Sooman A, Macintyre S, Anderson A. Scotland's health--a more difficult challenge for some? The price and availability of healthy foods in socially contrasting localities in the west of Scotland. Health Bull (Edinb) 1993;51(5):276-84.

19. Drewnowski A, Darmon N, Briend A. Replacing fats and sweets with vegetables and fruits--a question of cost. Am J Public Health 2004;94(4):1555-9.

20. Cade J, Upmeier H, Calvert C, Greenwood D. Costs of a healthy diet: analysis from the UK Women's Cohort Study. Public Health Nutr 1999;2(4):505-12.

21. Whitaker RC, Wright JA, Pepe MS, Seidel KD, Dietz WH. Predicting obesity in young adulthood from childhood and parental obesity. N Engl J Med 1997;337(13):869-73.

22. Nielsen LA, Nielsen TR, Holm JC. The Impact of Familial Predisposition to Obesity and Cardiovascular Disease on Childhood Obesity. Obes Facts 2015;8(5):319-28.

23. Bouchard C, Tremblay A, Després JP, Thériault G, Nadeau A, Lupien $\mathrm{PJ}$, et al. The response to exercise with constant energy intake in identical twins. Obes Res 1994;2(5):400-10. 
24. Bouchard C, Tremblay A, Després JP, Nadeau A, Lupien PJ, Thériault $G$, et al. The response to long-term overfeeding in identical twins. N Engl J Med 1990;322(21):1477-82.

25 . Behavior, environment, and genetic factors all have a role in causing people to be overweight and obese. Center for Disease Control and Prevention. Avaliable at: https://www.cdc. gov/genomics/resources/diseases/obesity/index.htm. Accessed Mar 11, 2020.

26. Mokdad AH, Marks JS, Stroup DF, Gerberding JL. Actual causes of death in the United States, 2000. JAMA 2004;291(10):123845.

27. Wadden TA, Webb VL, Moran CH, Bailer BA. Lifestyle modification for obesity: new developments in diet, physical activity, and behavior therapy. Circulation 2012;125(9):1157-70.

28. Donnelly JE, Blair SN, Jakicic JM, Manore MM, Rankin JW, Smith BKet al. American College of Sports Medicine Position Stand. Appropriate physical activity intervention strategies for weight loss and prevention of weight regain for adults. Med Sci Sports Exerc 2009;41(2):459-71.

29. Lindsay AR, Hongu N, Spears K, Idris R, Dyrek A, Manore MM. Field assessments for obesity prevention in children and adults: physical activity, fitness, and body composition. J Nutr Educ Behav 2014;46(1):43-53.

30. Chan RS, Woo J. Prevention of overweight and obesity: how effective is the current public health approach. Int J Environ Res Public Health 2010;7(3):765-83. 